\title{
A mandibular supernumerary supplemental incisor
}

\author{
Pratik B Kariya, ${ }^{1}$ Sweta Singh, ${ }^{2}$ Rachappa Mallikarjuna, ${ }^{1}$ Ankita Arora ${ }^{1}$
}

${ }^{1}$ Department of Pedodontics and Preventive Dentistry, K M Shah Dental College and Hospital, Sumandeep Vidyapeeth, Vadodara, Gujarat, India

${ }^{2}$ Department of Public Health Dentistry, Babu Banarasi Das College of Dental Sciences, Lucknow, Uttar Pradesh, India

\section{Correspondence to} Dr Rachappa Mallikarjuna mmrachappa@gmail.com

Accepted 15 March 2014

\section{Q Crossmark}

To cite: Kariya $\mathrm{PB}$, Singh $\mathrm{S}$, Mallikarjuna $\mathrm{R}$, et al. BMJ Case Rep Published online: [please include Day Month Year] doi:10.1136/bcr-2014204044

\section{DESCRIPTION}

An 11-year-old girl presented with malaligned lower front teeth. Medical and family histories did not reveal any relevant positive findings. Intraoral examination revealed class I molar relationship with crowding in lower arch. A supernumerary tooth on the lingual aspect of right mandibular central incisor was observed which was morphologically similar to the permanent mandibular central incisor (figure 1). Radiographic examination revealed the supernumerary tooth to be truly supplemental as it resembled mandibular central incisors (figure 2). The patient was advised for extraction of the supplemental incisor followed by the orthodontic treatment, but the patient was not willing to undergo extraction.

A supplemental supernumerary tooth has the same morphology as a normal tooth. Prevalence of supernumerary teeth is higher in the maxillary anterior region but is a rare finding in the mandibular anterior region which accounts for only about $1 \%$ of all supernumerary teeth. ${ }^{1}$ Complications associated with supernumerary teeth are many such as delayed or ectopic eruption of adjacent teeth, crowding, development of midline diastema, formation of dentigerous cyst, impaction and root resorption of adjacent teeth. ${ }^{2}{ }^{3}$

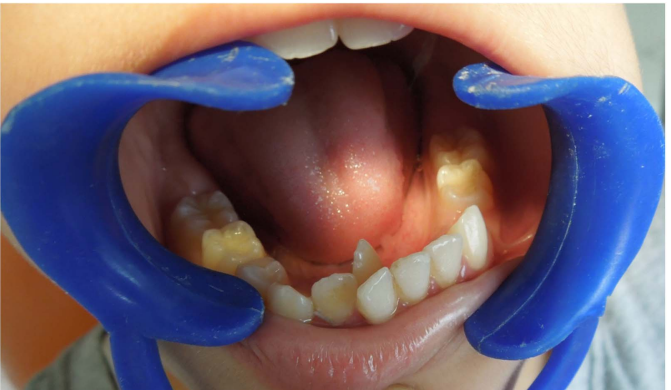

Figure 1 Intraoral photograph showing mandibular supplemental incisor.

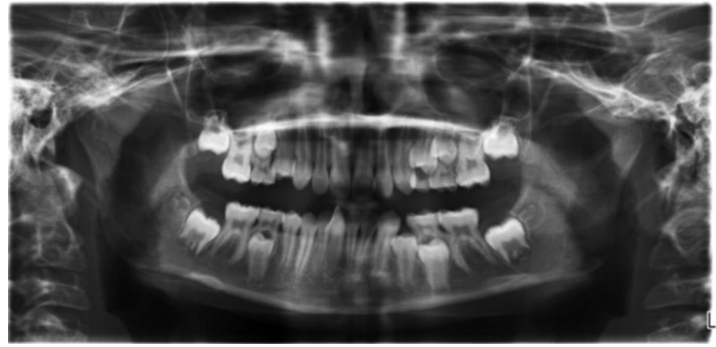

Figure 2 Orthopantamogram of 11-year-old child showing supplemental mandibular incisor.

\section{Learning points}

Supplemental supernumerary teeth in mandibular arch are usually very rare and difficult to differentiate from the permanent teeth because of the similar morphological characteristics.

- Presence of supplemental supernumerary mandibular central incisor may lead to lower anterior crowding and gingival problems.

- Supplemental supernumerary teeth usually have the same proportions of enamel, dentin and pulp tissue as that of normal teeth.

\section{Competing interests None.}

Patient consent Obtained.

Provenance and peer review Not commissioned; externally peer reviewed.

\section{REFERENCES}

1 Rajab LD, Hamdan MAM. Supernumerary teeth: review of literature and a survey of 152 cases. Int J Pediatr Dent 2002;12:244-54.

2 Hattab FN, Yassin OM, Rawashdeh MA. Supernumerary teeth: report of three cases and review of the literature. ASDC J Dent Child 1994;61:382-93.

3 Mitchell L. Supernumerary teeth. Dent Update 1989;16:65-9.

\footnotetext{
Copyright 2014 BMJ Publishing Group. All rights reserved. For permission to reuse any of this content visit http://group.bmi.com/group/rights-licensing/permissions.

BMJ Case Report Fellows may re-use this article for personal use and teaching without any further permission.

Become a Fellow of BMJ Case Reports today and you can:

- Submit as many cases as you like

- Enjoy fast sympathetic peer review and rapid publication of accepted articles

- Access all the published articles

- Re-use any of the published material for personal use and teaching without further permission

For information on Institutional Fellowships contact consortiasales@bmjgroup.com

Visit casereports.bmj.com for more articles like this and to become a Fellow
} 